Biological and Clinical Sciences Research Journal

ISSN: 2708-2261

www.bcsrj.com

DOI: https://doi.org/10.54112/bcsri.v2020i1.39

Biol. Clin. Sci. Res. J., Volume, 2020: 39

Original Research

\title{
ABO AND RHESUS BLOOD GROUP DISTRIBUTION IN URBAN AREA OF SOUTHERN PUNJAB MULTAN PAKISTAN
}

\author{
BHUTTA AM ${ }^{1 *}$, TASAWAR $Z^{1}$, SAJID $M^{1}$, HAYAT $S^{2}$, ALI A $^{2}$, MALIK A ${ }^{2}$ \\ ${ }^{1}$ Institute of Pure and Applied Biology, Bahauddin Zakariya University, Multan, Pakistan \\ ${ }^{2}$ Institute of Molecular Biology and Biotechnology, The University of Lahore, Lahore, Pakistan \\ *Corresponding author E-mail: ucanfindarif@gmail.com
}

(Received, $5^{\text {th }}$ June 2020, Revised $10^{\text {th }}$ November 2020, Published $16^{\text {th }}$ November 2020)

\begin{abstract}
This study was conducted to find out the distribution of $A B O$ phenotypes frequencies in urban area of Southern Punjab Multan Pakistan. A total of 1087 subjects (both male \& female) were taken and their blood samples were tested for $A B O$ blood group \& Rh. by using anti sera of ABO blood grouping i.e. Anti-D, Anti-A and Anti-B, and confirmed by standard technique. Doubtful results were checked by tube method. The data was analyzed by applying Pearson correlation and chi square test. In the present study overall prevalence of blood group \& Rh. positive was $997 / 1087$ (91.72\%) as compared to 90/1087 (8.28\%) blood group \& Rh. negative ( $P<0.05)$. It is a part of evolution with a natural and random genetic drift selection. ABO blood group types were equally distributed but there was no significant difference in both sexes. However, among ABO blood group \& Rh positive; dominance frequency was ' $B$ ' positive with 373 (34.32\%) followed by 'O' positive 293 (26.95\%), 'A' positive 218 (20.06\%) and 'AB' positive with frequency of $113(10.40 \%)$ respectively, and among $A B O$ blood group \& $R$. negative; ' $O$ ' negative was more prevalent with $42(3.86 \%)$ followed by ' $B$ ' negative $23(2.12 \%)$, 'A' negative $22(2.02 \%)$, and 'AB' negative with frequency of $03(0.28 \%)$ respectively In the present study $A B O$ blood group ' $B$ ' positive was dominant as compared to other $A B O$ blood groups \& Rh positive $(P>0.05)$. Analysis of the data collected in the present study indicated that there was a dominant frequency of $A B O$ blood group \& Rh. positive as compared to $R h$. negative, and blood group ' $B$ ' positive was dominant as compared to other ABO blood group types. The determination of the frequency of $A B O$ blood group types in urban area Southern Punjab Multan would help us in understanding the distribution of $A B O$ phenotypes. Whereas, the differences of $A B O$ blood group's frequencies in different races and regions is a part of evolution with a natural and random genetic drift selection.
\end{abstract}

Keywords: rhesus, $\mathrm{ABO}$ blood group, antigens, dominance, genetic draft, correlation

\section{Introduction}

The frequency of $\mathrm{ABO}$ blood group types are distributed variably in different regions and races. The differences of $\mathrm{ABO}$ blood groups frequencies in different races is a part of evolution. Blood group is genetically determined antigen, detected on the surface of the cell by specific antibodies and classified into four groups i.e. $\mathrm{A}, \mathrm{B}, \mathrm{AB}$ and $\mathrm{O}$ (Land-Stainer and Wiener, 1940). Others blood groups exist but known blood groups are 15 types. $\mathrm{ABO} \&$ Rhesus blood group system has importance in transfusion of blood and organ transplant. It has also importance in ancestral relation, genetic and evolution of humans. ABO blood system has reactive agglutinins in the serum that not have corresponding antigens. In addition, few researches have showed an association between different diseases and $\mathrm{ABO}$ blood group system (Pinkston and Cole, 1996). It has been observed by Garratty (2005) that blood group $\mathrm{ABO}$ antigens do have a biological role and various sure link with diseases to $\mathrm{ABO}$ blood group type was observed e.g. blood group A is linked with higher risk of cancer, and blood group $\mathrm{O}$ is associated with lower risk of cancer (Bai-Lin et al., 2014; Naeem et al., 2020ab). Khan (1988) studied the distribution of $\mathrm{ABO}$ blood group types in Britain \& USA and reported that incidence of blood group ' $A$ ' and ' $O$ ' were more common there. Similar results were also observed in Saudi Arabia by Moslem and Shashi (1989). While population of Egyptians has no blood groups ' $\mathrm{A}$ ' and 'AB' negative and it may be characteristic of Egyptians population. Blood group ' $A$ ' was more common in Europe particularly in Central Europe reported by Daean (2005), similarly blood group 'A' was more common in west Bengal reported by Datta et al., (1997) and, blood group 'B' was more common in Northern India and in Central Asia reported by Encyclopedia (2002). Generally Pakistani population has high prevalence of blood group 'B', while in some part of Pakistan blood group 'B' was reported dominant, while in other part blood group ' $\mathrm{O}$ ' was dominant as reported by Shah et al. (1990) and Mabood et al., (1993). Therefore, it is

[Citation: Bhutta, A.M., Tasawar, Z., Sajid, M., Hayat, S., Ali, A., Malik, A. (2020). ABO and Rhesus blood group distribution in urban area of southern Punjab Multan Pakistan. Biol. Clin. Sci. Res. J., 2020: 39. doi: https://doi.org/10.54112/bcsrj.v2020i1.39] 
no doubt that occurrence of $\mathrm{ABO}$ blood group varies in different regions, races and from community to community and some races has dominance of one blood group than others.

\section{Materials and methods}

The current survey was conducted to find out the ABO blood group \& Rh. frequencies in urban area of Southern Punjab Multan Pakistan. Blood sample was drawn; using disposable syringes by venous puncture and instantly shifted into EDTA vials and stored at$20^{\circ} \mathrm{C}$ until used for biochemical analysis. Total blood samples were collected from 1087 subjects visited at private laboratories for blood donation, and brought these blood samples labeled by subject name, age and sex to the well-equipped lab at Institute of Pure and Applied Biology Bahuddin Zakariya University Multan for the analysis. Blood samples of patients were tested for $\mathrm{ABO}$ blood group \& $\mathrm{Rh}$. by using ABO blood grouping anti sera i.e. Anti-D, Anti-A and Anti-B and confirmed by standard technique. If red blood cells showed agglutination by mixing with Anti- A, it was called type blood group A, if red blood cells showed agglutination by mixing with Anti- B, it was called type blood group B, if red blood cells showed no agglutination with Anti- A and with Anti- B, it was called blood group O, and if red blood cells showed agglutination by mixing with
Anti- D, it was called Rh. Positive if no agglutination called Rh. Negative. Doubtful results were checked by tube method. The data was analyzed by applying Pearson correlation and chi square test.

\section{Results}

A total of 1087 subjects (505 men, 582 women) were included in this study based on a detailed questionnaire for epidemiological studies and overall prevalence of blood group \& Rh. positive was 997/1087 (91.72\%) as compared to 90/1087 (8.28\%) blood group \& $\mathrm{Rh}$. negative $(\mathrm{P}<0.05)$. It is is a part of evolution with a natural and genetic drift selection. ABO blood group types were equally distributed but there was no significant difference in both sexes. However, among ABO blood group \& Rh positive; dominance frequency was ' $\mathrm{B}$ ' positive with 373 (34.32\%) followed by 'O' positive 293 (26.95\%), 'A' positive $218(20.06 \%)$ and 'AB' positive with frequency of $113(10.40 \%)$ respectively, and among ABO blood group \& $\mathrm{Rh}$. negative; 'O' negative was more prevalent with $42(3.86 \%)$ followed by ' $\mathrm{B}$ ' negative $23(2.12 \%)$, ' $A$ ' negative $22(2.02 \%)$, and 'AB' negative with frequency of $03 \quad(0.28 \%)$ respectively. In the present study blood group ' $B$ ' positive was dominant as compared to another $\mathrm{ABO}$ blood groups \& Rh positive ( $\mathrm{P}>0.05)$.

Table 1. Distribution of ABO \& Rhesus Blood Group Types among 1087 Subjects

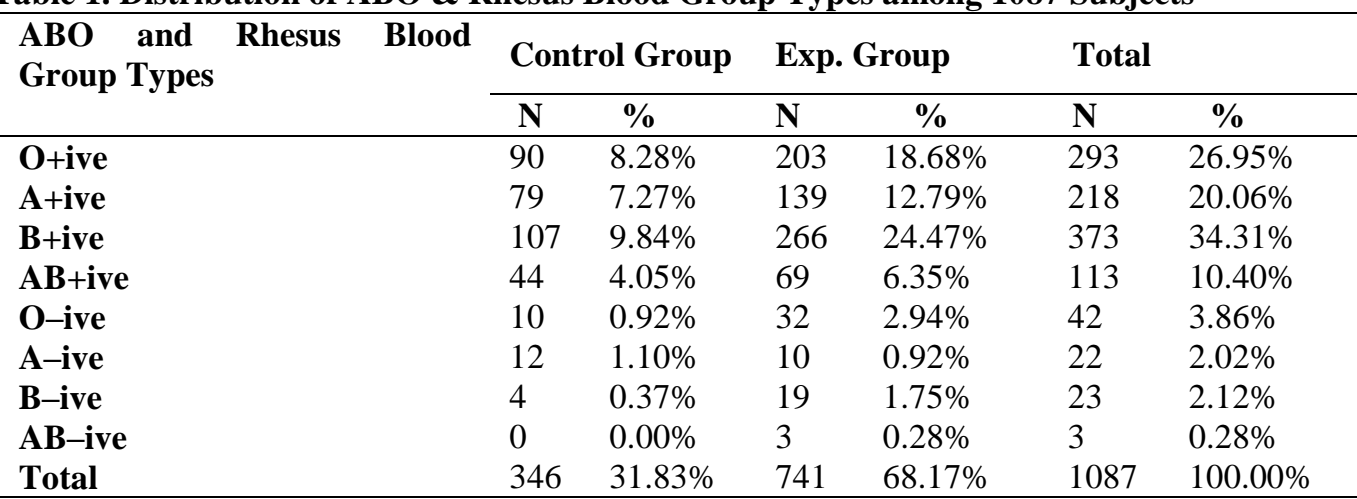

\section{Discussion}

The frequency of $\mathrm{ABO}$ blood group types are distributed variably in different regions and races. The differences of $\mathrm{ABO}$ blood groups frequencies in different races is a part of evolution. ABO blood groups are one set of (antigens), which are genetically determined carbohydrate molecules carried on the surface of membranes of red blood corpuscles (Umit et al., 2008). The biological role of blood groups relates to the presence of chemical on the other cells that were initially identified as red cell antigens and act as receptors for bacteria, parasites or viruses. In the present study the overall prevalence of ABO blood group \& Rh. positive was (91.72\%) as compared to $(8.28 \%)$ ABO blood group \& Rh. negative. Overall ABO blood group \& Rh. positive and $\mathrm{ABO}$ blood group type ' $\mathrm{B}$ ' positive was dominant as compared to ABO blood groups \& Rh. negative as shown in Table- 1 . Similar results in the population of Lahore were appraised by Umer et al. (2014), according to their results more frequent blood group was 'B' (37.8\%) followed by ' $\mathrm{O}$ ' (28.8\%), 'A' $(24.2 \%)$ and 'AB' $(9.1 \%)$ in blood donor, while in rhesus system $93.0 \%$ were Rh. positive and $7.0 \%$ were $\mathrm{Rh}$. negative. Similarly results of the present study were also appraised by Wikipedia (2017) reported $\mathrm{ABO}$ blood group distribution in Pakistan was as follows i.e. blood group ' $\mathrm{B}$ ' positive with

[Citation: Bhutta, A.M., Tasawar, Z., Sajid, M., Hayat, S., Ali, A., Malik, A. (2020). ABO and Rhesus blood group distribution in urban area of southern Punjab Multan Pakistan. Biol. Clin. Sci. Res. J., 2020: 39. doi: https://doi.org/10.54112/bcsrj.v2020i1.39] 
(34.40\%) followed by ' $\mathrm{O}$ ' positive $(24.63 \%)$, ' $\mathrm{A}$ ' positive $(20.6 \%)$ and ' $A B$ ' positive with overall prevalence of $(9.52 \%)$ respectively and among $\mathrm{ABO}$ blood group \& $\mathrm{Rh}$. negative; 'O' negative was more prevalent with $(4.17 \%)$ followed by ' $B$ ' negative (3.57\%), ' $\mathrm{A}$ ' negative $(2.66 \%)$ and ' $\mathrm{AB}$ ' negative with overall prevalence of $(0.45 \%)$ respectively.

In the present study as it was observed that in the rhesus system $91.72 \%$ were $\mathrm{Rh}$. positive and $8.28 \%$ were $\mathrm{Rh}$. negative. The present study results were appraised by Shah et al. (1990), according to their results $\mathrm{ABO}$ blood group negative was $5 \%$ only as compared to $\mathrm{ABO}$ blood group positive, this is in accordance to the present study which had showed low frequency of $\mathrm{ABO}$ blood group negative as compared to $\mathrm{ABO}$ blood group positive. Similar result were by Ilyas et al. (2013) who stated that $\mathrm{ABO}$ blood group \& Rh. positive was dominant with prevalence of $92.03 \%$ and $7.97 \%$ were with $\mathrm{ABO}$ blood group \& Rh. negative. In the present study frequency of blood group ' $\mathrm{B}$ ' was dominant with prevalence of $34.32 \%$ followed by ' $O$ ' positive $26.95 \%$, 'A' positive $20.06 \%$ and blood group 'AB' positive was least prevalent with $10.40 \%$ respectively. Similar results were reported by a study carried out from both urban and rural areas of Gujranwala (Pakistan) by Ilyas et al. (2013) that mostly common dominant blood group was ' $\mathrm{B}$ ' with $35.36 \%$ followed by blood group ' $\mathrm{O}$ ' with $32.41 \%$, blood group 'A' with $22.91 \%$ and blood group ' $\mathrm{AB}$ ' was least prevalent with $9.32 \%$. The results of the present study were supported by Babar et al. (1999) who also reported similar results that blood group ' $\mathrm{B}$ ' had highest frequency with prevalence of $(32.4 \%)$ followed by group ' $\mathrm{A}$ ' and ' $\mathrm{O}$ ' were (27.12\%) and (29.80\%), and group ' $\mathrm{AB}$ ' had the lowest (11.04\%) frequency respectively, and $92.88 \%$ subjects were $\mathrm{Rh}$ positive, while $7.12 \%$ of the population was $\mathrm{Rh}$. negative in District Noshera Pakistan. Similar results were also appraised by Khan et al. (2017) that group 'B' (32.0\%) was dominant, followed by "O" $(29.8 \%)$, "A" $(27.4 \%)$ and "AB" groups with overall lower frequency of $(10.8 \%$ ), while in Rhesus system $93.0 \%$ were $\mathrm{Rh}$. +ive and $7.0 \% \mathrm{Rh}$. -ive in the population of District Nowshera, Pakistan. The results of the present study were also supported by Carol and Melvin (1973), according to them blood group 'B' had its higher incidence in India and adjacent Central Asia and its occurrence diminishes both towards East and West, falling to single digit percentages in Spain. The prevalence of $\mathrm{ABO}$ blood group is distributed variably in different races and regions and could be explained on the basis that the difference of $\mathrm{ABO}$ blood group's frequencies in different races and regions is a part of evolution with a natural and random genetic drift selection. According to the results of the present study it could be explained on the basis that the distribution of $\mathrm{ABO}$ blood group Rh. positive and dominancy of blood group type 'B' in our population of Southern Punjab Multan Pakistan is a part of evolution with a natural and random genetic drift selection. However, the need for ABO blood groups study in our population was multipurpose and provided a baseline data for future research. The determination of the frequency of ABO blood groups in this urban area of Southern Punjab Multan would help us in understanding the distribution of 'ABO' phenotypes and association of various diseases.

\section{References}

Babar, M., Hassan, H. S., Habib-ullah and Hassan, M. K. (1999). ABO and Rhesus Blood Group Distribution in Disrict Nowshera. Journal of Postgraduate Medical Institute, 13, 02.

Carol, R. E. and Melvin, E. (1973). "Blood type B is completely absent in most North and South American Indians ". Anthropology., (http://books.google.com/?id=fvp FAAAAMAAJ).

Daean (2005). Blood Type A: Central and Europe. 2.1. 4, (http://www.ncbi.nlm.nih.gov/books/NBK226 4/\#ch2.1.4Ch.).

Datta, U. K., Mondal, S. and Mukhrjee, S. (1997). A study of the distribution of ABO and Rh. (D) blood groups among Lodha- Tribe in Midnapore District of West Bengal. Journal of Indian Medical Association 95, 497-99.

Garratty, G. (2005). Relationship of blood groups to disease: do blood groups antigens have a biological role? Revista Médica del Instituto Mexicano del Seguro Social, 43: 113-21.

Ilyas, M., Iftikhar, M. and Usman, R. (2013). Frequency of $\mathrm{ABO}$ and $\mathrm{Rh}$ Blood groups in Gujranwala (Punjab), Pakistan. Biologia 59, 107-14.

Khan, B. H., Attaullah, S., and Khan, A. H. (2017). Frequency of $\mathrm{ABO}$ and $\mathrm{RH}(\mathrm{D})$ blood groups involving volunteer donors in District Nowshera. Journal of Postgraduate Medical Institute 31, 135-37.

Khan, M. R. (1988). Biochemistry text book. Carvan Press Darbar Market, Lahore 1988: 58

Land-stainer, K. and Wiener, A. S. (1940). An agglutinable factor in human blood recognized by immune sera for rhesus blood. Proceedings of the Society for Experimental Biology and Medicine 43, 22.

[Citation: Bhutta, A.M., Tasawar, Z., Sajid, M., Hayat, S., Ali, A., Malik, A. (2020). ABO and Rhesus blood group distribution in urban area of southern Punjab Multan Pakistan. Biol. Clin. Sci. Res. J., 2020: 39. doi: https://doi.org/10.54112/bcsrj.v2020i1.39] 
Mabood, N., Mohammad, W. and Banuri, F. (1993). Frequency of $\mathrm{ABO}$ and $\mathrm{Rh}$ (D) blood groups in Mardan. Journal of Ayub Medical Collage $6,18$.

Moslem, U. M. and Shashi, A. (1989). Haemoglobin levels and blood groups in person living at high altitude. Annals of Saudi Medicine 9, 458.

Naeem, M., Malik, A., Ali, Q., Khalid, M., Masud, S. and Bhutta, A.M., (2020a). Hepatitis B and C prevalence and its associated risk factors among school going children in urban and rural areas of District Muzaffar Garh, Pakistan. Genetics and Molecular Research 19(1). gmr16039975

Naeem, M., Hassan, S., Masud, S., Ali, Q., Naeem, A.D. and Naeem, Z., (2020b). Comparative analysis of genomic DNA extraction protocols: Maxi-preparation of quality DNA for genetic evaluation and phylogenetic studies. Genetics and Molecular Research 19(1), gmr16039976.

Pinkston, J. A. and Cole, P. (1996). ABO blood groups and salivary gland tumor. Cancer Causes Control 6, 572.

Qureshi, M. A. and Bhatti, R. (2003). Frequency of ABO blood groups among the Diabetes Mellitus type 2 patients. Journal of the College of Physicians and Surgeons Pakistan 13, 453-55.

Shah, S. H., Subhani, F., Haqh, and Aslam, M. J. (1990). Frequency of ABO and Rh (D) blood groups in Lahore. Journal of Science and Technology 14, 107-9.

Umer, K. M., Waqas, B. M., Rehman, R. and Rizwan, A. K. (2014). Frequency of ABO and $\mathrm{Rh}$ (D) Blood groups among blood donors in Lahore, Pakistan. International Journal of Advanced Biological and Biomedical Research 2, 597-600.

Umit, T., Tiftik, E. N., Sakir, U., Ozrur, G., Tamer, I. K. and Handan, C. (2008). Relationship between ABO blood group and skin. Dermatology Online Journal 11, 1-6.

Wikipedia, (2017). ABO Blood type distribution by country- Available at: http://en.wikipedia . org/wiki/Blood_type_distribution_by_country .Wikimedia Foundation, Inc.,

Zhang, Bai-Lin., Na-He., Yu-Bei, H., Feng-Ju, S. and Ke-Xin, C. (2014). ABO Blood Groups and Risk of Cancer: a Systematic Review and Meta-analysis. Asian Pacific Journal of Cancer Prevention 15, 4643-50

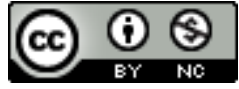

Open Access This article is licensed under a Creative Commons Attribution 4.0 International License, which permits use, sharing, adaptation, distribution and reproduction in any medium or format, as long as you give appropriate credit to the original author(s) and the source, provide a link to the Creative Commons licence, and indicate if changes were made. The images or other third party material in this article are included in the article's Creative Commons licence, unless indicated otherwise in a credit line to the material. If material is not included in the article's Creative Commons licence and your intended use is not permitted by statutory regulation or exceeds the permitted use, you will need to obtain permission directly from the copyright holder. To view a copy of this licence, visit http://creativecommons.org/licen ses/by/4.0/.

(C) The Author(s) 2021

[Citation: Bhutta, A.M., Tasawar, Z., Sajid, M., Hayat, S., Ali, A., Malik, A. (2020). ABO and Rhesus blood group distribution in urban area of southern Punjab Multan Pakistan. Biol. Clin. Sci. Res. J., 2020: 39. doi: https://doi.org/10.54112/bcsrj.v2020i1.39] 